\title{
Productiveness Response and Quality of Fruits of Tomato Under Different Levels of Fertilizers and Irrigation
}

\author{
Fábio Teixeira Delazari ${ }^{1}$, Mariane Gonçalves Ferreira Copati ${ }^{1}$, Flávia Maria Alves ${ }^{1}$, Ronaldo Silva Gomes ${ }^{1}$, \\ Bruno Soares Laurindo ${ }^{1}$, Renata D. F. Laurindo ${ }^{1}$, Hermínia Emília Prieto Martinez ${ }^{1}$ \\ \& Derly José Henriques da Silva ${ }^{1}$ \\ ${ }^{1}$ Departament of de Fitotecnia, Universidade Federal de Viçosa, Viçosa, MG, Brazil \\ Correspondence: Mariane Gonçalves Ferreira Copati, Departament of de Fitotecnia, Universidade Federal de \\ Viçosa, University Campus, 36570-900 Viçosa, MG, Brazil. Tel: 55-319-9234-6780. E-mail: \\ marianegonferreira@gmail.com
}

$\begin{array}{lr}\text { Received: March 11, } 2019 & \text { Accepted: April 19, } 2019 \quad \text { Online Published: June 30, } 2019 \\ \text { doi:10.5539/jas.v11n9p62 } & \text { URL: https://doi.org/10.5539/jas.v11n9p62 }\end{array}$

\begin{abstract}
The mineral fertilizing and the supply of water seem to influence the content of lycopene in the fruits of tomato, thus it is crucial to elucidate the ideal levels of fertilizers and the adequate management of irrigation for this crop. Hence, the study had an objective to evaluate the efficiency of different levels of mineral fertilizing and the effect of irrigation management on the productivity as well as on the lycopene content in the fruits of tomato. For this, two experiments in Winter/Spring and Summer/Autumn were carried out. The treatments consisted of the combination of different levels of mineral fertilizersing with nitrogen, phosphorous, and potassium along with two levels of irrigation. The productivity of fruits, the production of large fruits, the lycopene content, and the efficiency in the use of nutrients, were evaluated. With the application of $120 \%$ of the recommended dose of fertilizing, the productivity of large fruits was maximum. The efficiency in the use of nitrogen, phosphorous, and potassium was maximum with the application of 120, 121 and 50\% of the recommended dose of fertilizing, respectively, and $100 \%$ of the irrigation depth. The maximum content of lycopene was obtained, by applying $200 \%$ of the fertilizing dose and $50 \%$ of the irrigation depth. The best combination for the production of large fruits, higher lycopene content, and higher efficiency in the use of nitrogen, phosphorous, and potassium, was the application of $120 \%$ of the dosage of fertilizing and $100 \%$ of the irrigation depth.
\end{abstract}

Keywords: carotenoids, fertilizing, irrigation, nutrient use efficiency, Solanum lycopersicum L.

\section{Introduction}

Tomato (Solanum lycopersicum L.) is the vegetable with the second largest volume of production worldwide, surpassed only by potato (FAOSTAT, 2017), with production to be estimated in 170 millions of tons. But most of it is intended for fresh consumption (FAOSTAT, 2017; WPTC, 2015). Brazil represents a vast producer of tomato, with a production estimated in more than 4 millions of tons (FAOSTAT, 2017). The state of Minas Gerais represents the third bulky producer in this country, being responsible for $12 \%$ of the national production in 2016 (IBGE, 2015).

Besides its economic importance, the tomato plays an important nutritional role, being an important source of vitamin $\mathrm{C}$ and of precursors of vitamin A (Leiva-Brondo et al., 2012). A remarkable nutritional aspect in fruits of tomato consists on the presence of a high number of components essential for human health, especially those with antioxidant activity (Ilahy et al., 2011). The antioxidant activity related to the consumption of tomato result from the presence of components such as Vitamin $\mathrm{C}$ in its fruits, and especially from components such as $\beta$-carotene and lycopene (Perveen et al., 2015).

The lycopene represents most of the carotenoid content in tomato. This carotenoid has biological as well as physic-chemical properties that bestow it a high antioxidant activity, especially helping in the deactivation of singlet oxygen and the scavenging of free radicals (Islamian \& Mehrali, 2015). Therefore, the consumption of foods with higher contents of lycopene reduces the risks of a series of critical pathologies such as cardiovascular diseases and cancers (Aune et al., 2012; Eliassen et al., 2015), justifying the demand for foods with higher contents of this bioactive component. 
The content of lycopene in tomato varies considerably between genotypes of this species (Perveen et al., 2015), and between the stages of maturation of fruits (Ilahy et al., 2011). Studies also report a pronounced effect of the water regime (Pernice et al., 2010; Pék et al., 2014) and fertilization (Kuscu et al., 2014) on the concentration of carotenoids in fruits of tomato. In general, these studies show that two factors namely: (a) the reduction of irrigation, and (b) the imposition of water stress in tomato, have caused an increase in the carotenoid content in fruits. On the other hand, some of these studies show that water stress decreases lycopene content in some varieties of tomato, pointing to the need to optimize the reduction of irrigation in tomatoes targeting a higher nutritional quality of fruits.

The crop of tomato demands differentiated fertilization for each region of cultivation (Silva et al., 2011). Additionally, the recommendations for mineral fertilizing in tomato rarely are updated, although the modern cultivars possess productive thresholds higher than those cultivated in the past. This confirms the importance of updating the levels of mineral fertilizing in tomato. For this, it is pertinent that the agronomic characteristics and the fruit quality of tomato be studied at different levels of fertilization and water supply of production of this crop.

Thus, the objective of this study was to evaluate the productivity, the lycopene content and the efficiency of nutrients use in tomato in the region of Zona da Mata, Minas Gerais, Brazil.

\section{Materials and Methods}

\subsection{Seasons and Experimental Conditions of the Experiments}

Two experiments were carried in two different seasons for testing the response of the treatments in contrasting seasons. The first experiment, from June to November 2013 (Winter/Spring), and the second from January to May 2014 (Summer/Autumn) was conducted, both in the Department of Plant Science, in the Federal University of Viçosa, in Viçosa, Minas Gerais, Brazil. The experiments were located at $20^{\circ} 45^{\prime} \mathrm{S}$ latitude and e $42^{\circ} 52^{\prime} \mathrm{W}$ longitude.

According to the texture analysis of soil, the soil in the first experiment, \{according to the classification of Lemos and Santos (1996)\}, was classified as clay soil $(0-40 \mathrm{~cm})$, and as frank-clay-sandy $(0-20 \mathrm{~cm})$ and clay-sandy $(20-40 \mathrm{~cm})$ in the second. The chemical characteristics of the soil were also evaluated (Table 1).

Table 1. Chemical properties of the soil in the experimental areas in the two cropping seasons Winter/Spring and Summer/Autumn. Viçosa, Minas Gerais state, Brazil. 2013/2014

\begin{tabular}{|c|c|c|c|c|}
\hline \multirow{2}{*}{$\begin{array}{l}\text { Experiment } \\
\text { Depth }(\mathrm{cm})\end{array}$} & \multicolumn{2}{|c|}{ Winter/Spring } & \multicolumn{2}{|c|}{ Summer/Autumn } \\
\hline & $0-20$ & $20-40$ & $0-20$ & $20-40$ \\
\hline $\mathrm{pH} \mathrm{H} \mathrm{H}_{2} \mathrm{O}$ & 5.3 & 5.3 & 5.3 & 5.3 \\
\hline $\mathrm{P}\left(\mathrm{mg} \mathrm{dm} \mathrm{m}^{-3}\right)$ & 24.6 & 35.8 & 35.1 & 35.1 \\
\hline $\mathrm{K}\left(\mathrm{mg} \mathrm{dm}^{-3}\right)$ & 120 & 89 & 186 & 123 \\
\hline $\mathrm{Ca}^{2+}\left(\mathrm{cmol}_{\mathrm{c}} \mathrm{dm}^{-3}\right)$ & 3.1 & 2.9 & 2.3 & 2.6 \\
\hline $\mathrm{Mg}^{2+}\left(\mathrm{cmol}_{\mathrm{c}} \mathrm{dm}^{-3}\right)$ & 0.8 & 0.7 & 0.7 & 0.6 \\
\hline $\mathrm{Al}^{3+}\left(\mathrm{cmol}_{\mathrm{c}} \mathrm{dm}^{-3}\right)$ & 0 & 0 & 0 & 0 \\
\hline $\mathrm{H}+\mathrm{Al}\left(\mathrm{cmol}_{\mathrm{c}} \mathrm{dm}^{-3}\right)$ & 3.96 & 3.47 & 3.8 & 4.13 \\
\hline $\mathrm{T}\left(\mathrm{cmol}_{\mathrm{c}} \mathrm{dm}^{-3}\right)$ & 8.17 & 7.3 & 7.28 & 7.64 \\
\hline $\mathrm{V}(\%)$ & 52 & 52 & 48 & 46 \\
\hline MO $\left(\operatorname{dag~kg}^{-1}\right)$ & 3.1 & 2.86 & 2.63 & 2.75 \\
\hline P-rem $\left(\mathrm{mg} \mathrm{L}^{-1}\right)$ & 34.5 & 34.5 & 35.1 & 33.8 \\
\hline $\mathrm{Zn}\left(\mathrm{mg} \mathrm{dm}^{-3}\right)$ & 3.4 & 3.3 & 7 & 7.2 \\
\hline $\mathrm{Fe}\left(\mathrm{mg} \mathrm{dm}^{-3}\right)$ & 48.4 & 70.6 & 145.5 & 159.8 \\
\hline $\operatorname{Mn}\left(\mathrm{mg} \mathrm{dm}^{-3}\right)$ & 46.8 & 56.7 & 71.3 & 73.2 \\
\hline $\mathrm{Cu}\left(\mathrm{mg} \mathrm{dm}^{-3}\right)$ & 2.3 & 3.2 & 5 & 4.8 \\
\hline $\mathrm{B}\left(\mathrm{mg} \mathrm{dm}^{-3}\right)$ & 0.2 & 0.1 & 0.4 & 0.3 \\
\hline
\end{tabular}

Note. Mehlich I* was used to extract available $\mathrm{P}, \mathrm{K}, \mathrm{Fe}, \mathrm{Zn}, \mathrm{Mn}$, and $\mathrm{Cu}$, whereas $\mathrm{KCl}\left(1 \mathrm{~mol} \mathrm{~L}^{-1}\right)$ was used to extract $\mathrm{Ca}, \mathrm{Mg}$, and Al. Potential acidity to $\mathrm{pH} 7.0$ with calcium acetate obtained from $1 \mathrm{~mol} \mathrm{~L}^{-1}$; B from hot water.

* Mehlich-1 is an extractor that acts by acid dissolution, due to the presence of sulfuric and hydrochloric acids to estimate the available levels of nutrients. 


\subsection{Genotype Information, Prepare of Seedlings and Cultivation Management}

We evaluated the commercial hybrid Carina TY, which is commercialized by the Sakata Seed-Brazil. This hybrid is a salad tomato with undetermined growth, widely cultivated in Brazil. This hybrid has a high productive potential along with high quality of fruits.

The seedlings were produced in polystyrene trays with 128 cells using the commercial substrate Golden Mix (Amafibra), made of coconut fiber. The seedlings were transplanted when they had 3 to 4 fully expanded leaves. The arrangement of plants resulted in a density of 2.5 plants $\mathrm{m}^{-2}$, and a population of 25.000 plants $\mathrm{ha}^{-1}$. The agricultural management was performed on a weekly basis, thereby controlling the pests and diseases whenever required, according to the recommendations of Valenciano and Toril (2015).

\subsection{Fertilizing}

Before the setting of the experiment, the acidity of the soil was corrected and the fertilizing was performed according to the recommendation of fertilizer used in the state of Minas Gerais, Brazil, known as the Quinta Aproximação (Ribeiro et al., 1999) (Table 2).

Table 2. Recommendation of fertilizing used in the state of Minas Gerais, Brazil, adapted from the Quinta Aproximação, Ribeiro et al. (1999)

\begin{tabular}{|c|c|c|c|}
\hline \multicolumn{4}{|l|}{ Planting fertilizing } \\
\hline \multirow{2}{*}{ Availability of $\mathrm{P}$ and $\mathrm{K}$} & \multicolumn{3}{|c|}{ Doses } \\
\hline & $\mathrm{N}$ & $\mathrm{P}_{2} \mathrm{O}_{5}$ & $\mathrm{~K}_{2} \mathrm{O}$ \\
\hline & \multicolumn{3}{|c|}{ - } \\
\hline Low & 0 & 900 & 80 \\
\hline Medium & 0 & 800 & 60 \\
\hline Good & 0 & 600 & 40 \\
\hline Excellent & 0 & 400 & 0 \\
\hline \multicolumn{4}{|l|}{ Post planting fertilizing } \\
\hline \multirow{2}{*}{ Period of application } & \multicolumn{3}{|c|}{ Doses } \\
\hline & $\mathrm{N}$ & $\mathrm{P}_{2} \mathrm{O}_{5}$ & $\mathrm{~K}_{2} \mathrm{O}$ \\
\hline $1^{\text {st }}$ to $4^{\text {th }}$ Week & 30 & 80 & 40 \\
\hline $5^{\text {th }}$ to $8^{\text {th }}$ Week & 60 & 48 & 70 \\
\hline $9^{\text {th }}$ to $14^{\text {th }}$ Week & 90 & 36 & 130 \\
\hline After the $15^{\text {th }}$ Week & 120 & 0 & 180 \\
\hline
\end{tabular}

However, the initial fertilizing in the experiments was not carried out. Further, the adjustment of the $\mathrm{pH}$ of the soil, with the application of $410 \mathrm{~kg} \mathrm{ha}^{-1}$ (in the first experiment), and $395 \mathrm{~kg} \mathrm{ha}^{-1}$ (in the second experiment) of dolomitic limestone, RPTN (Relative Power Total Neutralization) $=85 \%$, was performed. The limestone was applied at $20 \mathrm{~cm}$, one week before the transplantation, in both the experiments.

The fertilizing was gradually applied in the irrigation pipe with a venturi injector, from the first week of transplantation. The fertilizers used in both experiments were mono-ammonium phosphate (MAP), calcium nitrate $\left(\mathrm{Ca}_{3}(\mathrm{NO})_{2}\right)$, potassium chloride $(\mathrm{KCl})$, and magnesium sulfate $\left(\mathrm{MgSO}_{4}\right)$ and the fertilizing was further divided into 18 sessions in both the experiments.

\subsection{Irrigation Management}

The calculation of the water requirement was done based on the estimation of the Crop Evapotranspiration (ETc), and the frequency of irrigation was between 2 to 3 days. The crop water requirement was determined using the adjustment coefficients corresponding to the Reference Evapotranspiration $\left(\mathrm{ET}_{0}\right)$. The net irrigation depth was calculated based on the water balance, taking into account the input and output of the water irrigation.

The evapotranspiration was estimated by using the following equations, proposed by (Allen et al., 1998; Allen \& Pereira, 2009):

$$
\mathrm{ETc}=\mathrm{ET}_{0} \times \mathrm{Kc}
$$

and,

$$
\mathrm{Kc}=(\mathrm{Kcb} \times \mathrm{Ks})+\mathrm{Ke}
$$


where, ETc $=$ Crop Evapotranspiration $\left(\mathrm{mm} \mathrm{d}^{-1}\right)$, ETo $=$ Reference Evapotranspiration $\left(\mathrm{mm} \mathrm{d}^{-1}\right), \mathrm{Kc}=$ Crop Coefficient, $\mathrm{Kcb}=$ Crop Basal Coefficient, $\mathrm{Ke}=$ Soil Evaporation Coefficient, and $\mathrm{Ks}=$ Stress Coefficient. The ETc was determined, using the initial, intermediate, and final Kcb values which corresponded to $0.15,1.15$, and 0.70 , respectively (Allen et al., 1998). The frequency of irrigation and the total amount of water applied (irrigation + rainfall) varied between the treatments (Table 3 ).

Table 3. Rain and irrigation applied during the conduction of the experiments in the two cropping seasons: Winter/Spring and Summer/Autumn

\begin{tabular}{lllll}
\hline Experiments & Irrigation $\left(\% \mathrm{ET}_{\mathrm{c}}\right)$ & Rain $(\mathrm{mm})$ & Irrigation $(\mathrm{mm})$ & Rain and Irrigation $(\mathrm{mm})$ \\
\hline \multirow{2}{*}{ Winter/Spring } & 50 & 257 & $123(44)^{\mathrm{a}}$ & 380 \\
& 100 & 257 & $236(44)$ & 493 \\
\multirow{2}{*}{ Sumer/Autumn } & 50 & 317 & $91(21)$ & 408 \\
& 100 & 317 & $171(21)$ & 488 \\
\hline
\end{tabular}

Note. The values in parentheses correspond to the number of irrigation events.

The treatments involving the irrigation depths were started 19 days after the transplantation (DAT), when the plants had 119 Degree Days (DD), and continued during the phases of development, production and harvest. The values of DD used as a reference to these three phases of development corresponded to 306, 661 and 1246 DD, respectively.

\subsection{Weather Variables in the Experiments}

The average temperature in the cultivation area was $18.5^{\circ} \mathrm{C}$ in the first experiment and $20.9^{\circ} \mathrm{C}$ in the second. The precipitation rate was $257.4 \mathrm{~mm}$ in the first experiment, and $315.4 \mathrm{~mm}$ in the second. The solar radiation in the first experiment was $15.9 \mathrm{MJ} \mathrm{m}^{-2}$, and in the second was $16.6 \mathrm{MJ} \mathrm{m}^{-2}$. The estimate of the relative humidity was $83 \%$ in the first experiment, and $84 \%$ in the second (Figures $1 \mathrm{~A}-1 \mathrm{~B}$ ).
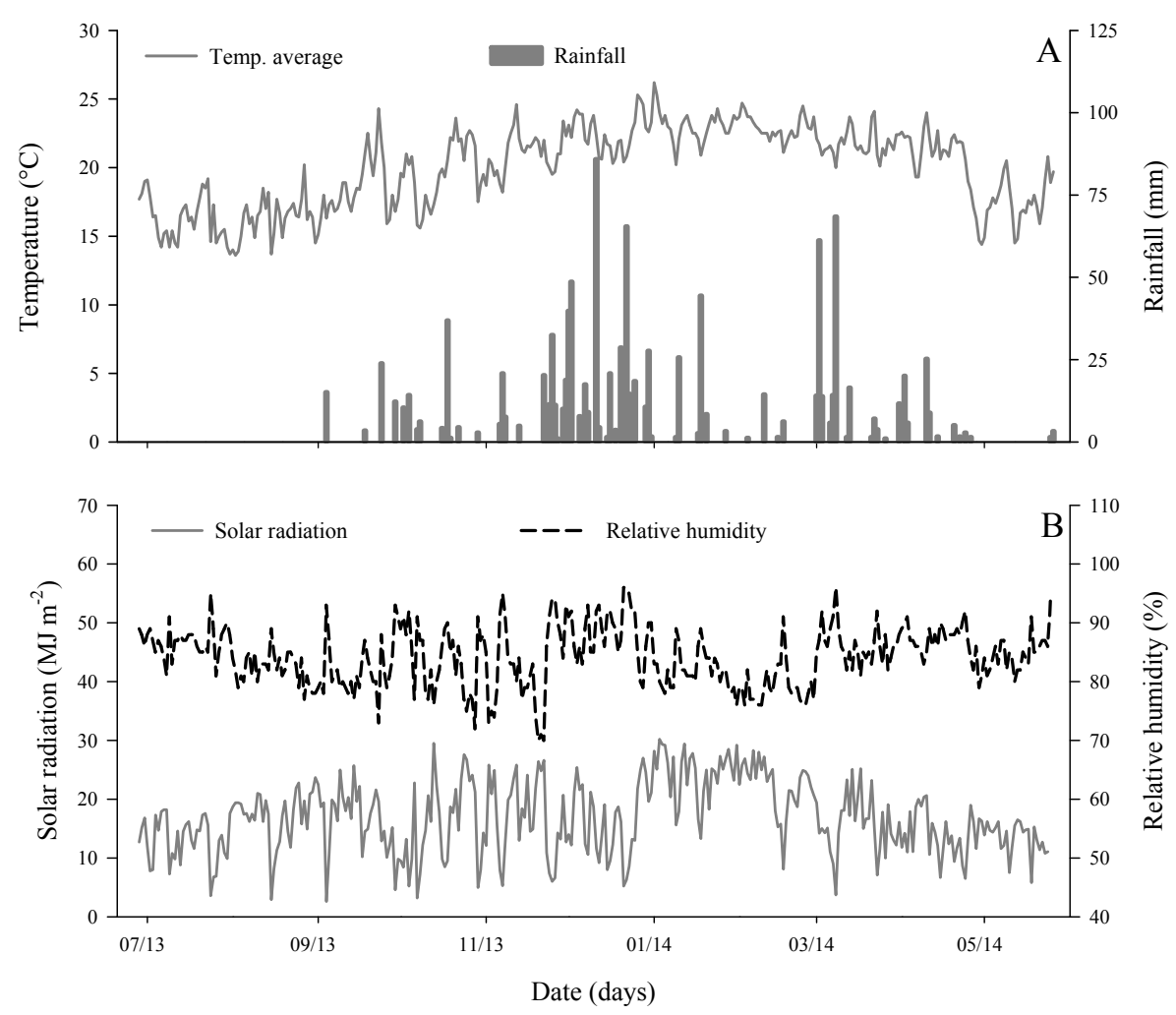

Figure 1. Average, minimum, and maximum: critical temperatures, precipitation, solar radiation, specific solar radiation, and relative humidity, during the experiments in Viçosa, Minas Gerais, Brazil 


\subsection{Experimental Design}

The data from 14 cultivation rows ( $14 \mathrm{~m}$ long, with a total area of $392 \mathrm{~m}^{2}$ ) was collected, considering the central plants as the experimental plot and the end of rows as borders. The experimental plot with an area of $1.6 \mathrm{~m}^{2}$ consisted of 4 plants. The plots consisted of rows of $3 \mathrm{~m}$ with 15 plants and had a total area of $6 \mathrm{~m}^{2}$.

The experiments were conducted in a randomized block in a split-plot design, with three replications. The plots allocated 50,100,150, and $200 \%$ of the recommended fertilizing (Table 4), while for sub-plots allocated 50 and $100 \%$ of the Etc-Crop Evapotranspiration $\left(\mathrm{mm} \mathrm{d}^{-1}\right)$.

Table 4. Doses of nutrients applied in experiments in the two cropping seasons Winter/Spring and Summer/Autumn

\begin{tabular}{|c|c|c|c|c|c|c|}
\hline \multirow{2}{*}{ Treatments } & \multicolumn{3}{|c|}{ Winter/Spring } & \multicolumn{3}{|c|}{ Sumer/Autumn } \\
\hline & $\mathrm{N}$ & $\mathrm{P}$ & $\mathrm{K}$ & $\mathrm{N}$ & $\mathrm{P}$ & K \\
\hline & \multicolumn{6}{|c|}{ 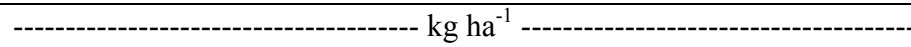 } \\
\hline $50 \%$ & 113 & 232 & 235 & 101 & 250 & 192 \\
\hline $100 \%$ & 226 & 463 & 470 & 202 & 500 & 384 \\
\hline $150 \%$ & 339 & 695 & 705 & 303 & 750 & 576 \\
\hline $200 \%$ & 452 & 926 & 940 & 404 & 1000 & 768 \\
\hline
\end{tabular}

\subsection{Experimental Evaluations}

With an aim, to evaluate the productivity, the fruits were harvested and were classified into three commercial classes based on their diameter (d) values: (1) large: $\mathrm{d}>60 \mathrm{~mm}$, (2) medium: $50 \mathrm{~mm} \leq \mathrm{d}<60 \mathrm{~mm}$, and (3) small: $40 \mathrm{~mm} \leq \mathrm{d}<50 \mathrm{~mm}$.

The pulp of the fruits was analyzed by spectrophotometry at a wavelength of $470 \mathrm{~nm}$ to obtain the concentration of lycopene, which was further calculated according to the following equation:

$$
\text { Lycopene concentration }=\mathrm{A} \times \mathrm{V} \times 10.000 \times \mathrm{D} /\left(\mathrm{m} \times \mathrm{E}_{\mathrm{cm}}^{1 \%}\right)
$$

where,

$\mathrm{A}=$ absorbance of the solution at a $470 \mathrm{~nm}$ wavelength; $\mathrm{V}=$ sample final volume $(\mathrm{ml}) ; \mathrm{D}=$ sample dilution; $\mathrm{m}=$ sample weight $(\mathrm{g}) ; \mathrm{E}_{1 \mathrm{~cm}}{ }^{1 \%}=$ specific coefficient of molar absorption for lycopene in petroleum ether (3450), (Rodriguez-Amaya, 2001).

The efficiency in the use of nitrogen (NUE), phosphorus (PUE), and potassium (KUE) was determined based on the relationship between productivity $(\mathrm{P})$, and the amount of each nutrient applied $(\mathrm{N}, \mathrm{P}$, and $\mathrm{K})$. The above parameter was calculated using the equation given below:

$$
\operatorname{NUE}(\mathrm{N})=\mathrm{P} / \mathrm{N}
$$

where, NUE $=$ efficiency in the use of nitrogen $\left(\mathrm{kg} \mathrm{kg}^{-1}\right), \mathrm{P}=$ productivity $\left(\mathrm{kg} \mathrm{ha}^{-1}\right)$, and $\mathrm{N}=$ amount of nitrogen applied $(\mathrm{kg})$. Similarly, the efficiency in the use of $\mathrm{P}$ and $\mathrm{K}$ was estimated.

The results were analyzed using regression and the models were chosen based on the significance of the regression coefficients, using the " $\mathrm{t}$ " test at the probability of 1 and $5 \%$. The analysis was carried out in the statistical program $R$.

\section{Results}

\subsection{Productivity of fruits}

The reduction on the ETc from 100 to 50\% reduced the productivity and the efficiency in the use of nutrients.

The quadratic model was the one that best adjusted to the total productivity, considering the interaction between the factors under study (Figures 2A and B). With the application of $146.43 \%\left(114.27 \mathrm{t} \mathrm{h}^{-1}\right)$ and $145.65 \%(95.23$ $\mathrm{t} \mathrm{ha}^{-1}$ ) of the recommended dose of fertilization in the Winter/Spring and Summer/Autumn, respectively, the estimated maximum productivity with $50 \%$ of ETc was achieved (Figure $2 \mathrm{~A}$ ). On the other hand, with $120.45 \%$ $\left(134.11 \mathrm{t} \mathrm{ha}^{-1}\right)$ of the recommended fertilization in the winter/spring, and $120.80 \%\left(105.88 \mathrm{t} \mathrm{ha}^{-1}\right)$ in the summer/autumn, the maximum productivity with $100 \%$ of ETc was reached (Figure 2B). The highest productivity $\left(134.11 \mathrm{t} \mathrm{ha}^{-1}\right)$ corresponded to the winter/spring trial, applying $100 \%$ of ETc, and $120.80 \%$ of the 
recommended fertilization. This fertilization was equivalent to $272.23,557.71$, and $566.14 \mathrm{~kg} \mathrm{ha}^{-1}$ of $\mathrm{N}$, P, and $\mathrm{K}$, respectively.

$50 \%$ ETc
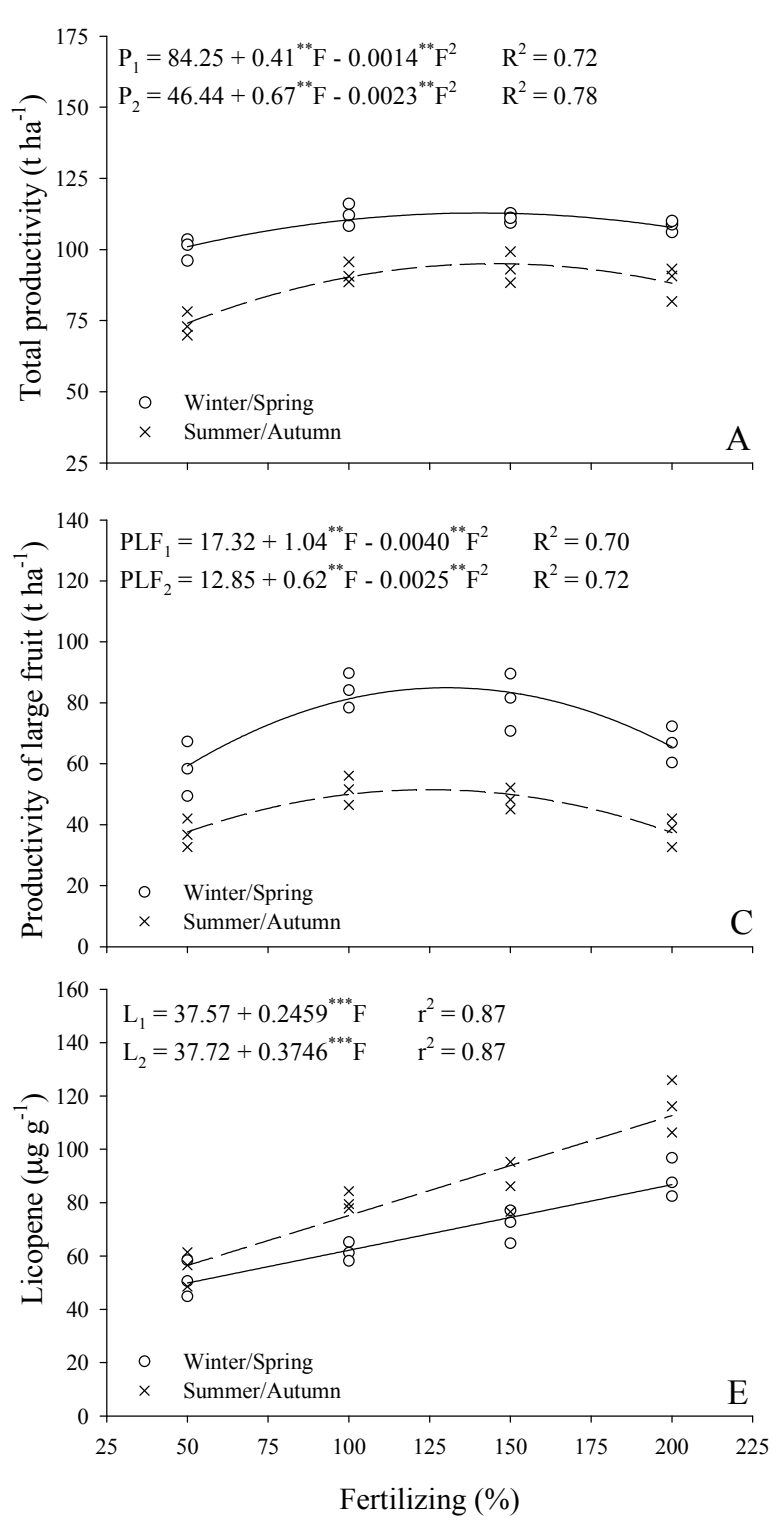

$100 \% \mathrm{ETc}$

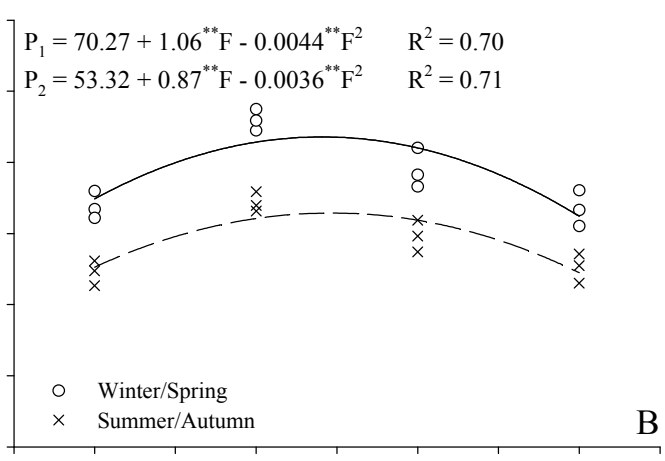

$\mathrm{PLF}_{1}=43.16+0.90^{* * * *} \mathrm{~F}-0.0037^{* * * *} \mathrm{~F}^{2} \quad \mathrm{R}^{2}=0.78$

$\mathrm{PLF}_{2}=15.70+0.82^{* * * *} \mathrm{~F}-0.0032^{* * * *} \mathrm{~F}^{2} \quad \mathrm{R}^{2}=0.73$

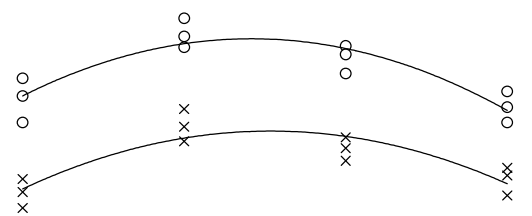

Winter/Spring Summer/Autum $\mathrm{D}$

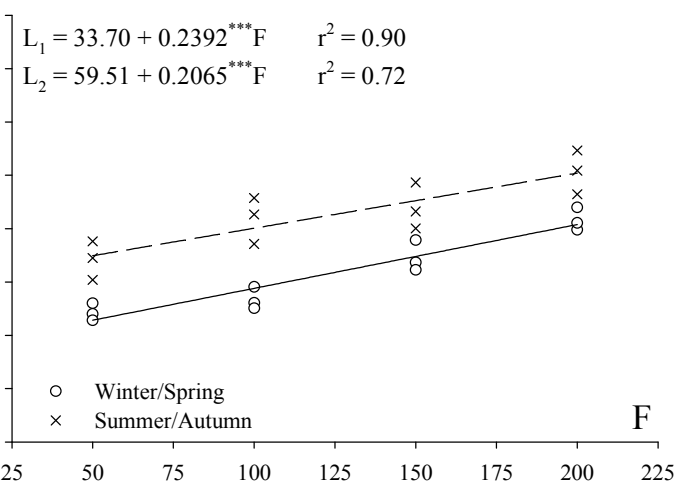

Fertilizing (\%)

Figure 2. The total productivity of fruits (A and B), productivity of large fruits $(\mathrm{C}$ and $\mathrm{D})$ and the content of lycopene in the fruits $(\mathrm{E}$ and $\mathrm{F})$, under different levels of fertilizing and at two irrigation depths (50 and 100\% ETc). $* * *$ Significant at $0.1 \%$; * Significant at $1 \%$; * and significant at $5 \%$ by the " $t$ " test

\subsection{Estimates of the Lycopene Content}

The content of lycopene showed a linear trend and reached maximum values with $200 \%$ of the fertilization and $50 \%$ of ETc in the winter/spring $\left(86.7 \mu \mathrm{g} \mathrm{g}^{-1}\right)$ and summer/Autumn $\left(112.6 \mu \mathrm{g} \mathrm{g}^{-1}\right)$, Figure 2E). The maximum content of lycopene in the winter/spring $\left(81.50 \mu \mathrm{g} \mathrm{g}^{-1}\right)$ and summer/fall $\left(100.8 \mu \mathrm{g} \mathrm{g}^{-1}\right)$, was reached with $100 \%$ of ETc and $200 \%$ of the fertilization (Figure 2F).

\subsection{The Efficiency in the Use of Nutrients}

The mathematical quadratic model was the one that best adjusted to the efficiency in the use of nutrients. The efficiency in the use of $\mathrm{P}$ and $\mathrm{K}$, decreased with the increase of doses of fertilization and reached a maximum with $50 \%$ of ETc in the winter/spring $\left(881 \mathrm{~kg} \mathrm{~kg}^{-1}\right)$ and summer/fall $\left(726 \mathrm{~kg} \mathrm{~kg}^{-1}\right)$ (Figure 3A). As shown in the 
Figure 3B, the efficiency in the use of $\mathrm{N}$ was higher with the application of $100 \%$ of ETc in the winter/spring $\left(972 \mathrm{~kg} \mathrm{~kg}^{-1}\right)$ as well as in summer/autumn $\left(856 \mathrm{~kg} \mathrm{~kg}^{-1}\right)$. However, the maximum efficiency in the use of $\mathrm{P}$ was attained, with $50 \%$ of ETc in the winter/spring $\left(429 \mathrm{~kg} \mathrm{~kg}^{-1}\right)$ and summer/autumn $\left(293 \mathrm{~kg} \mathrm{~kg}^{-1}\right)$, (Figure 3C).

$50 \%$ ETc
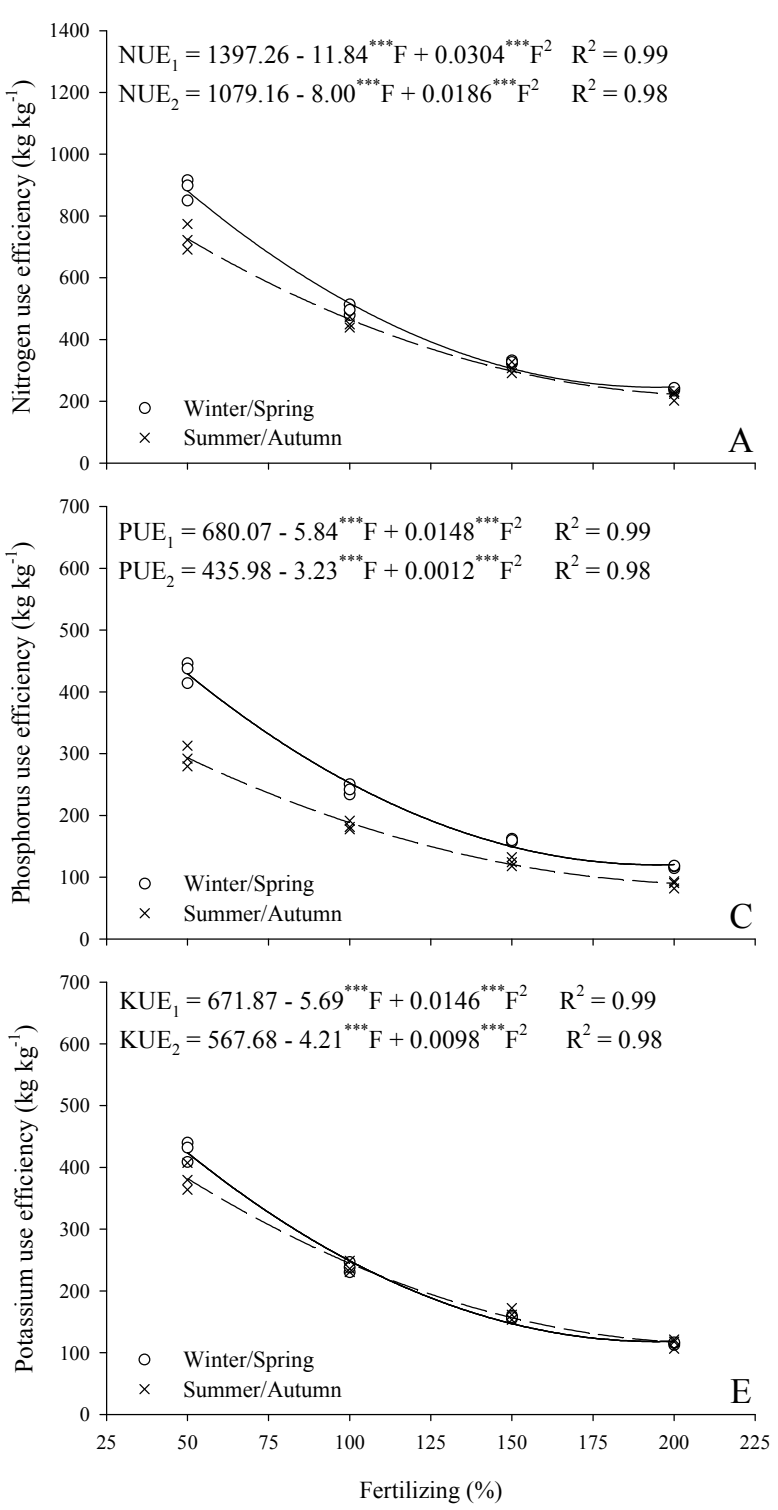

$100 \%$ ETc

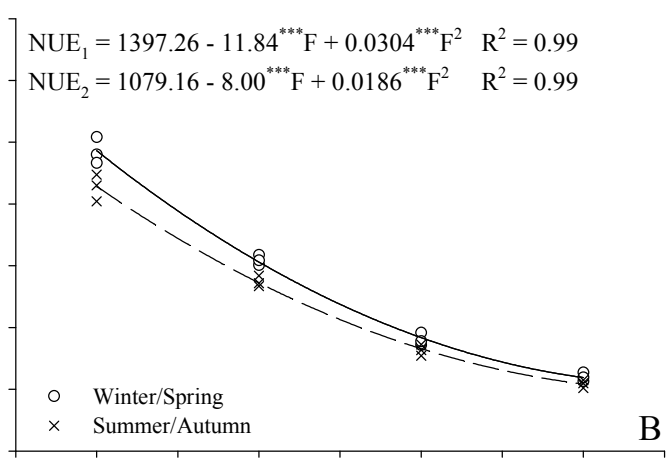

$\mathrm{PUE}_{1}=704.47-5.17^{* * *} \mathrm{~F}+0.0112^{* * *} \mathrm{~F}^{2} \quad \mathrm{R}^{2}=0.99$

$\mathrm{PUE}_{2}=511.69-3.71^{* * *} \mathrm{~F}+0.0080^{* * *} \mathrm{~F}^{2} \quad \mathrm{R}^{2}=0.99$

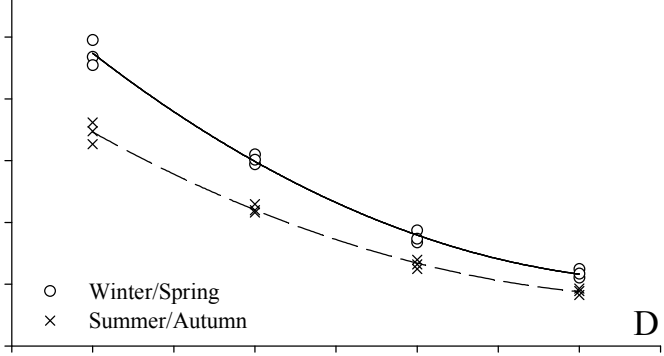

$\mathrm{KUE}_{1}=696.08-5.13^{* * * *} \mathrm{~F}+0.0111^{* * *} \mathrm{~F}^{2} \quad \mathrm{R}^{2}=0.99$

$\mathrm{KUE}_{2}=666.26-4.83^{* * *} \mathrm{~F}+0.0104^{* * *} \mathrm{~F}^{2} \quad \mathrm{R}^{2}=0.99$

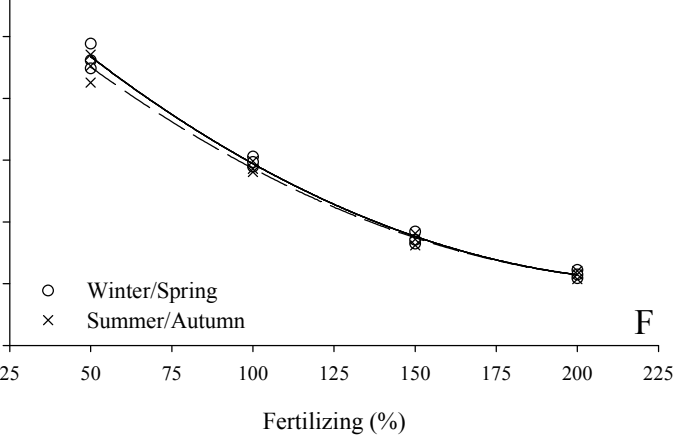

Figure 3. Efficiency in the use of nitrogen (A and B), phosphorus ( $\mathrm{C}$ and D), and potassium (E and F), under the different levels of fertilizing and at two irrigation depths (50 and 100\% ETc). *** Significant at $0.1 \%$; $* *$ significant at $1 \% ; *$ and significant at $5 \%$ by the " $\mathrm{t}$ " test

The maximum efficiency in the use of $\mathrm{K}$ with $50 \%$ of ETc was 424 and $382 \mathrm{~kg} \mathrm{~kg}^{-1}$ in the winter/spring and summer/autumn, respectively, (Figure 3E). With the application of $100 \%$ ETc, the maximum efficiency in the use of $\mathrm{K}$ was $468 \mathrm{~kg} \mathrm{~kg}^{-1}$ in the winter/spring and $450 \mathrm{~kg} \mathrm{~kg}^{-1}$ in summer/autumn (Figure $3 \mathrm{~F}$ ). Applying $50 \%$ of the recommended dose of fertilization provided a maximum efficiency in the use of $\mathrm{N}, \mathrm{P}$, and $\mathrm{K}$ in the winter/spring (1.45 $\left.\mathrm{t} \mathrm{ha}^{-1}\right)$, and summer/autumn $\left(1.38 \mathrm{t} \mathrm{ha}^{-1}\right)$.

\section{Discussion}

The decrease in productivity of tomato at $50 \%$ of ETc is associated with water deficit, since the irrigation depths below the consumption at $100 \%$, reduces the productivity as well as the number of large fruits in tomato (Silva et al., 2013; Kuscu et al., 2014; Biswas et al., 2015). The decrease in production in conditions of water deficit 
stems from effects that this condition has on (a) the photosynthetic processes, and (b) the efficiency in the use of nutrients by crops (Kreuzwieser \& Gessler, 2010; Celebi, 2014).

Fertilization directly affects tomato yield, as found for the productivity of the tomato variety Azad T-6 under the application of different levels of fertilizer (Kumar et al., 2013). Additionally, levels of fertilizer lower than the doses applied in this study provided maximum productivity in tomato (Zhang et al., 2010; Marouelli et al., 2015), which in turn, is attributed to the characteristics of the soil where these studies were carried out since the application of high levels of fertilizing might result in the leaching of nutrients. The contrast in the results obtained with the cultivars Karina TY and Azad T-6 may be attributed to differences in their genetic background, besides environmental differences between the areas where these cultivars have been studied such as soil, temperature, and precipitation (Zhang et al., 2010).

At evaluating the application of nitrogen and phosphorous by drip irrigation in processing tomato, Zhang et al. (2010) reported that the phosphorus did not affect the biomass of stems and leaves. These authors pointed out that this result stemmed from a probably high level of phosphorus in the soil followed by an increase in the diffusion of this nutrient with the drip irrigation.

The deficiency and excess of nutrients, especially of $\mathrm{N}, \mathrm{P}$, and $\mathrm{K}$, affect the metabolism of plants and, consequently, their productivity. However, when supplied in adequate levels, they are beneficial and essential to the growth and development, besides being closely associated to the synthesis and translocation of carbohydrate to the fruits (Araújo et al., 2010).

The increase in the production of larger fruits in tomato until specified doses of fertilizing (121.62 to 128. 13\%) is in agreement with the results found in a similar study involving this crop in Turkey (Kuscu et al., 2014). The increment in the production of larger fruits with the application of higher doses of nitrogen (60-120 $\left.\mathrm{kg} \mathrm{ha}^{-1}\right)$ was similar to the results reported for nitrogen $\left(0-120 \mathrm{~kg} \mathrm{ha}^{-1}\right)$, potassium $\left(0-75 \mathrm{~kg} \mathrm{ha}^{-1}\right)$, and phosphorus $(0-80 \mathrm{~kg}$ $\mathrm{ha}^{-1}$ ) in the production of processing tomato (Kumar et al., 2013). According to Ferreira et al. (2010), the increased productivity of larger fruits with the increase of fertilizing can be explained by enhanced synthesis of gibberellin in conditions where the availability of $\mathrm{N}$ is high. Moreover, the function of $\mathrm{P}$ is related to the transfer/storage of energy, which also influences the production of larger fruits.

Potassium is essential for the enzymes involved in the synthesis of lycopene, and according to some studies, the application of this nutrient is closely related to the content of lycopene in tomato (Fanasca et al., 2006; Taber et al., 2008).

The studies further revealed that the application of high doses of $\mathrm{K}$ in soil at different irrigation depths increased the lycopene content in fruits of tomato (Hartz et al., 2000; Helyes et al., 2009; Javaria et al., 2012). According to Javaria et al. (2012), this effect stems from the essential function that this nutrient plays in the acceleration of enzymatic activities responsible for the production of carotenoid. On the other hand, some studies have indicated that $\mathrm{K}$ does not affect the content of lycopene in tomato (Fontes et al., 2000, Taber et al., 2008). According to Taber et al. (2008), this occurs probably because the content of lycopene and the response of this crop to different levels of $\mathrm{K}$ vary according to the genetic background of the cultivars along with the changes in the temperature and precipitation in the regions of cultivations.

Further, irrigation with $50 \%$ of ETc increased the content of lycopene, suggesting that it can also affect the content of carotenoids in the fruits of tomato. This result is similar to those reported from a study on tomato in Turkey (Kuscu et al., 2014) and Hungary (Pék et al., 2014). Corroborating with these results, Liu et al. (2011), reported that drip irrigation decreased the content of lycopene in the fruits of tomato by $8 \%$, thereby suggesting that it indirectly affects the concentration of lycopene in the fruits of tomato. Thus, this occurs through the possible effect of dilution that irrigation has on the content of lycopene in fruits by promoting the production of larger fruits (Pék et al., 2014).

The higher productivity in tomato with the increase of the fertilizing can be explained, by the law of diminishing returns. This law states that from a certain level, the increase in the dosages of fertilizing results in a gradual decrease in the production, resulting in the use of nutrients less efficiently (Hawkesford, 2012). Usually, the nutritional demands of the crops exceed the increase of the doses of fertilizing, and as a result, the total sum of exceeding nutrients is not used by the plants in their physiological processes, resulting in lower efficiency in the use of nutrients (Zotarelli et al., 2009; Hawkesford, 2012).

The excessive application of fertilizing may result in losses by leaching, volatilization, and complexation in the soil (Hawkesford, 2012). These effects corroborate with the results reported for the efficiency in the use of nitrogen in tomato (Araújo et al., 2007; Zhang et al., 2010). The reduction in the efficacy of nitrogen utilization 
with an increase its doses, indicates that some of the nitrogen applied was not recovered in the plant tissues or might have been retained in the soil (Pires et al., 2015). Additionally, it is found that applying high doses of fertilizers, especially of $\mathrm{N}$, might result in (a) poor fixation, (b) reduction in the sugar content of fruits, and (c) reduction in the flavor of fruits (Dorais \& Papadopoulos, 2001; Stefanelli et al., 2010).

The significant impact of the doses of fertilization of phosphorous on its utilization efficacy highlights the response of plants towards doses of this nutrient. The commercial cultivation of tomato usually involves the application of large amounts of phosphorous. However, as pointed out by Macêdo et al. (2011), this crop does not require high levels of phosphorous for completing its biological processes, since this nutrient is subjected to specific adsorption in the soil and is not readily available to plants.

The reduction in the efficiency of potassium utilization in tomato may result in lower uptake of calcium and boron, besides enhancing the susceptibility towards physiological disorders in fruits such as splits (Huang \& Snapp, 2009). These authors also observed a higher sensibility of plants to the high concentration of salts, mainly during plant germination and development stage, indicating that the application of high doses of potassium elevated the saline concentration of this fertilizer and reduced the absorption of water and consequently the weight of fruits. Other concern resulting from the inappropriate employment of potassium via irrigation is the increase in the concentration of this nutrient in the soil and its consequent salinization (Hartz, 2009).

\section{Conclusion}

The productivity of tomato was found to be highest with $120 \%$ of the fertilizing and $100 \%$ of the irrigation depth. The content of lycopene was optimal with $200 \%$ of the fertilizing and $50 \%$ of the recommended irrigation. The efficiency in the use of $\mathrm{N}, \mathrm{P}$, and $\mathrm{K}$ was higher with a lower dose of fertilizing and $100 \%$ of the recommended irrigation depth. Therefore, the fertilizing dose of $120 \%$ and the application of $100 \%$ of the irrigation depth resulted in high yield, fruit quality and efficiency in the use of $\mathrm{N}, \mathrm{P}$ and $\mathrm{K}$.

\section{Acknowledgements}

This study was financed in part by the "Coordenação de Aperfeiçoamento de Pessoal de Nível Superior-Brasil (CAPES)-Finance Code 001" and "National Council for Scientific and Technological Development-CNPq".

\section{References}

Allen, R. G., \& Pereira, L. S. (2009). Estimating crop coefficients from fraction of ground cover and height. Irrigation Science, 28, 17-34. https://doi.org/10.1007/s00271-009-0182-z

Allen, R. G., Pereira, L. S., Raes, D., \& Smith, M. (1998). FAO Irrigation and Drainage Paper. Roma, Italy.

Araújo, C. De., Cezar, P., Fontes, R., \& Sediyama, C. S. (2007). Critérios para a determinação da dose de nitrogênio a ser aplicada no tomateiro em ambiente protegido. Horticultura Brasileira, 25, 327-332. https://doi.org/10.1590/S0102-05362007000300003

Aune, D., Chan, D. S. M., Vieira, A. R., Rosenblatt, D. A. N., Vieira, R., Greenwood, D. C., \& Norat, T. (2012). Dietary compared with blood concentrations of carotenoids and breast cancer risk: A systematic review and meta-analysis of prospective. The American Journal of Clinical Nutrition, 96, 356-373. https://doi.org/ 10.3945/ajcn.112.034165.1

Biswas, S. K., Akanda, A. R., Rahman, M. S., \& Hossain, M. A. (2015). Effect of drip irrigation and mulching on yield, water-use efficiency and economics of tomato. Plant, Soil and Environment, 61, 97-102. https://doi.org/10.17221/804/2014-PSE

Celebi, M. (2014). The effect of water stress on tomato under different emitter discharges and semi-arid climate condition. Bulgarian Journal of Agricultural Science, 20, 1151-1157.

Di Mascio, P., Kaiser, S., \& Sies, H. (1989). Lycopene as the most efficient biological carotenoid singlet oxygen quencher. Archives of Biochemistry and Biophysics, 274, 532-538. https://doi.org/10.1016/0003-9861(89) 90467-0

Dorais, M., \& Papadopoulos, A. P. (2001). Greenhouse tomato fruit quality. Horticultural Reviews, 26, 239-319. https://doi.org/10.1017/CBO9781107415324.004

Eliassen, H., Liao, X., Rosner, B., Tamimi, R., Tworoger, S., \& Hankinson, S. (2015). Plasma carotenoids and risk of breast cancer over $20 \mathrm{y}$ of follow-up1-3. The American Journal of Clinical Nutrition, 101, 1197-1205. https://doi.org/10.3945/ajcn.114.105080

Fanasca, S., Colla, G., Maiani, G., Venneria, E., Rouphael, Y., Azzini, E., \& Saccardo, F. (2006). Changes in antioxidant content of tomato fruits in response to cultivar and nutrient solution composition. Journal of 
Agricultural and Food Chemistry, 54, 4319-4325. https://doi.org/10.1021/jf0602572

FAOSTAT. (2017). Statistical databases. Retrieved from http://www.fao.org/faostat/en/\#data/QC

Hartz, T. K., Miyao, E. M., Mullen, R. J., \& Cahn, M. D. (2000). Potassium fertilization effects on processing tomato yield and fruit quality. Acta Horticulturae, 543, 127-133. https://doi.org/10.17660/ ActaHortic.2001.542.15

Hawkesford, M. J. (2012). Improving nutrient use efficiency in crops. Els, 1-7. https://doi.org/10.1002/ 9780470015902.a0023734

Helyes, L., Dimény, J., Bőcs, B., Schober, G., \& Pék, Z. (2009). The effect of water and potassium supplement on yield and licopene content of processing tomato. Acta Horticulturae, 823, 103-108. https://doi.org/ 10.17660/ActaHortic.2009.823.11

Huang, J., \& Snapp, S. S. (2009). Potassium and Boron Nutrition Enhance Fruit Quality in Midwest Fresh Market Tomatoes. Communications in Soil Science and Plant Analysis, 40, 1937-1952. https://doi.org/ $10.1080 / 00103620902896811$

IBGE (Instituto Brasileiro de Geografia e Estatistica). (2015). Retrieved from https:/www.ibge.gov.br/ estatisticas-novoportal/economicas/agricultura-e-pecuaria/9201-levantamento-sistematico-da-producao-agri cola.html? $=\& \mathrm{t}=$ downloads

Ilahy, R., Hdider, C., Lenucci, M. S., Tlili, I., \& Dalessandro, G. (2011). Phytochemical composition and antioxidant activity of high-lycopene tomato (Solanum lycopersicum L.) cultivars grown in Southern Italy. Scientia Horticulturae, 127, 255- 261. https://doi.org/10.1016/j.scienta.2010.10.001

Islamian, J. P., \& Mehrali, H. (2015). Lycopene as A Carotenoid Provides Radioprotectant and Antioxidant Effects by Quenching Radiation-Induced Free Radical Singlet Oxygen: An Overview. Cell Journal (Yakhteh), 16(4), 386-391.

Javaria, S., Khan, M. Q., \& Bakhsh, I. (2012). Effect of potassium on chemical and sensory attributes of tomato fruit. The Journal of Animal \& Plant Sciences, 22, 1081-1085.

Kreuzwieser, J., \& Gessler, A. (2010). Global climate change and tree nutrition: Influence of water availability. Tree Physiology, 30, 1221-1234. https://doi.org/10.1093/treephys/tpq055

Kumar, M., Meena, M. L., Kumar, S., Maji, S., \& Kumar, D. (2013). Effect of nitrogen, phosphorus and potassium fertilizers on the growth, yield and quality of tomato var. Azad T-6. The Asian Journal of Horticulture, 8, 616-619.

Kuscu, H., Turhan, A., Ozmen, N., Aydinol, P., \& Demir, A. O. (2014). Optimizing levels of water and nitrogen applied through drip irrigation for yield, quality, and water productivity of processing tomato (Lycopersicon esculentum Mill.). Horticulture, Environment, and Biotechnology, 55, 103-114. https://doi.org/10.1007/ s13580-014-0180-9

Leiva-Brondo, M., Valcárcel, M., Cortés-Olmos, C., Roselló, S., Cebolla-Cornejo, J., \& Nuez, F. (2012). Exploring alternative germplasm for the development of stable high vitamin $\mathrm{C}$ content in tomato varieties. Scientia Horticulturae, 133, 84-88. https://doi.org/10.1016/J.SCIENTA.2011.10.013

Lemos, R., \& Santos, R. (1996). Manual de descrição e coleta de solo no campo Sociedade Brasileira de Ciência do Solo (3rd ed.). Sociedade Brasileira de Ciência do Solo, Centro Nacional de Pesquisa de Solos, Campinas, SP.

Marouelli, W. A., Guimaraes, T. G., Braga, M. B., \& Silva, W. L. de C. (2015). Frações ótimas da adubação com fósforo no pré-plantio e na fertirrigação por gotejamento de tomateiro. Pesquisa Agropecuaria Brasileira, 50, 949-957. https://doi.org/10.1590/S0100-204X2015001000011

Pék, Z., Szuvandzsiev, P., Daood, H., Neményi, A., \& Helyes, L. (2014). Effect of irrigation on yield parameters and antioxidant profiles of processing cherry tomato. Open Life Sciences, 9, 383-395. https://doi.org/ 10.2478/s11535-013-0279-5

Pernice, R., Parisi, M., Giordano, I., Pentangelo, A., Graziani, G., Gallo, M., ... Ritieni, A. (2010). Antioxidants profile of small tomato fruits: Effect of irrigation and industrial process. Scientia Horticulturae, 126, 156-163. https://doi.org/10.1016/j.scienta.2010.06.021

Perveen, R., Suleria, H. A. R., Anjum, F. M., Butt, M. S., Pasha, I., \& Ahmad, S. (2015). Tomato (Solanum lycopersicum) carotenoids and lycopenes chemistry; metabolism, absorption, nutrition, and allied health 
claims - A comprehensive review. Critical Reviews in Food Science and Nutrition, 55, 919-929. https://doi.org/10.1080/10408398.2012.657809

Pires, M. V., Da Cunha, D. A., Carlos, S. D. M., \& Costa, M. H. (2015). Nitrogen-use efficiency, nitrous oxide emissions, and cereal production in Brazil: Current trends and forecasts. PLoS ONE, 10, 1-19. https://doi.org/ 10.1371/journal.pone.0135234

Ribeiro, A. C., Guimarães, P. T. G., \& Alvarez, V. H. (1999). Recomendações para o uso de corretivos e fertilizantes em Minas Gerais (5th ed.). Sociedade Brasileira de Ciência do Solo (SBCS), Viçosa.

Rodriguez-Amaya, D. B. (2001). A guide to carotenoid analysis in foods (p. 71). International Life Sciences Institute One Thomas Circle, N.W. Washington, D. C.

Silva, E. C., Maciel, G. M., Alvarenga, P. P. M., \& Paula, A. C. C. F. F. (2011). Teores de B-caroteno e licopeno em função das doses de fósforo e potássio em frutos de diferentes genótipos de tomateiro industrial. Bioscience Journal, 27, 247-252.

Silva, J. M., Ferreira, R. S., Melo, A. S., Suassuna, J. F., Dutra, A. F., \& Gomes, J. P. (2013). Cultivo do tomateiro em ambiente protegido sob diferentes taxas de reposição da evapotranspiração. Revista Brasileira de Engenharia Agricola e Ambiental, 17, 40-46. https://doi.org/10.1590/S1415-43662013000100006

Stefanelli, D., Goodwin, I., \& Jones, R. (2010). Minimal nitrogen and water use in horticulture: Effects on quality and content of selected nutrients. Food Research International, 43, 1833-1843. https://doi.org/ 10.1016/j.foodres.2010.04.0229

Taber, H., Perkins-Veazie, P., Li, S., White, W., Rodermel, S., \& Xu, Y. (2008). Enhancement of Tomato Fruit Lycopene by Potassium Is Cultivar Dependent. HortScience, 43, 159-165. https://doi.org/10.21273/ HORTSCI.43.1.159

Valenciano, J. D. P., \& Toril, J. U. (2015). Control System of Management for Intensive Cultivation Activity in Tomato Production: Spanish Case. Journal of Agricultural Science and Technology, 17, 11-21.

WPTC. (2015). World production estimate of tomatoes for processing. Retrieved from https://www.wptc.to/ releases-wptc.php

Zhang, T. Q., Tan, C. S., Liu, K., Drury, C. F., Papadopoulos, A. P., \& Warner, J. (2010). Yield and Economic Assessments of Fertilizer Nitrogen and Phosphorus for Processing Tomato with Drip Fertigation. Agronomy Journal, 102, 774. https://doi.org/10.2134/agronj2009.0346

Zotarelli, L., Dukes, M. D., \& Scholberg, J. M. S. (2009). Tomato nitrogen accumulation and fertilizer use efficiency on a sandy soil, as affected by nitrogen rate and irrigation scheduling. Agricultural Water Management, 96, 1247-1258. https://doi.org/10.1016/j.agwat.2009.03.019

\section{Copyrights}

Copyright for this article is retained by the author(s), with first publication rights granted to the journal.

This is an open-access article distributed under the terms and conditions of the Creative Commons Attribution license (http://creativecommons.org/licenses/by/4.0/). 